\title{
強震記録に基づく進化戦略手法による建物の振動特性評価 DYNAMIC CHARACTERISTICS OF A BUILDING ESTIMATED FROM STRONG MOTION RECORDS USING EVOLUTION STRATEGY
}

\author{
鹿嶋 俊 英*, 北川 良和** \\ Toshihide KASHIMA and Yoshikazu KITAGAWA
}

\begin{abstract}
Understanding of dynamic characteristics of building structures is a key issue in the seismic design technology. From this point of view, Building Research Institute (BRI) is operating the strong motion network for buildings since 1957. The BRI annex building is a one of the stations of the BRI strong motion network and densely instrumented with 22 accelerometers. In this paper, variation of dynamic characteristics of the annex building is discussed using strong motion records.

Decreasing of fundamental natural frequencies of the annex building with the passage of time is recognized from the optimizing analysis of 158 strong motion records using a single-degree-of-freedom system. 16 records with relatively big displacements are selected in order to examine such phenomena in detail. The Evolution Strategy (ES) is applied to the optimizing analysis using a multi-storey sway-rocking model. ES is a powerful problem-solving tool based on natural evolution. Building stiffness, rocking stiffness, swaying stiffness and building modal damping ratio are targets of the optimization. The rocking stiffness, the swaying stiffness and the modal damping ratio of the building show stable behavior with the passage of time. Consequently, it is confirmed that the decreasing of the natural frequencies is caused by the softening of the building stiffness.
\end{abstract}

Keywords: Strong motion observation, Dynamic characteristics of building, Soil-structure interaction, Sway-rocking model, Evolution Strategy

強震観測，建物の振動特性，地盤と建物の相互作用，スウェイーロッキングモデル，進化戦略

1. はじめに

地震時の建物への入力地震動の適切な評価と, それを受けた建物 応答の的確な把握は, 建物の霜震安全性を検討する上で重要な課題 のひとつである。建物と周辺地盤を対象とした強震観測は, これら の課題を解決するために貴重な資料を提供している。

1950年代から始まった日本の強震観測でも，初期の主要な観測対 象は建物であった1)。その後, 半世紀の間に建物の耐震設計技術は目 覚しく発展し, 強震観測の技術開発も進展とも相まって, 現在多く の機関が観測網を展開している2),3)。

一方, 強震記録の蓄積と, 動的解析技術の進展を背景とした超高

層建物など新しい構造の出現を受けて，1970年代から実験的手法に よる実在建物の振動特性の調查が盛んに行われるようになり4), その 後強震観測記録が蓄積されるに伴い, 地震記録からの建物の振動特 性の評価が進んできだ。

地震観測記録から建物の振動特性を議論する場合, 振動数領域で 伝達関数を推定する方法が一般的だが), 推定精度の向上や近接する 振動モードの分離, また非線形挙動への対応などの要求から, 近年 時間領域で振動パラメータを同定する手法が脚光を浴びている。

代表的なシステム同定の手法としては, 振動システムの入出力関 係を伝達関数(あるいはフィルタ)として多項式モデルで記述する ARX, ARMAXモデルなどが用いられ9), 多入力多出力の振動系にも
適用が拡張されている》。この同定方法はモデルの構成が単純でブラ ックボックス的に適用できるが, 次数の決定や物理パラメータとの 対応に工夫が必要とされている7。

また, システムを物理的な法則に基づきモデル化し，その物理量 を同定する方法もある。状態空間モデルが代表的な例で, カルマン フィルターによる同定多や予測䛊差法による同定帛が報告されている。 物理モデルを使う場合は, 物理パラメータが直接結果として得られ る利点があるが, 一般的に煩雑な計算が必要な場合が多く, またパ ラメータの数を適正に抑える必要がある(10), 11。最近では構造物のへ ルスモニタリングの観点から, 層咸性の変化を観測記録から検出す る研究も行われている ${ }^{11), 12) 。 ~}$

一方，観測記録を使った振動モデルのパラメータの同定は，最も 適したパラメータを探索する非線形最適化の問題と捉えることがで きる。最適化問題には多くの解法が存在し ${ }^{13)}$, 中でも1960年代に登場 した生物の進化の過程に範をとる進化的計算法は, その適用範囲の 広さや探索性能の高さから強力なッールである。遺伝的アルゴリズ ムは進化的計算法に分類される代表的な手法で, 逆解析や最適設計 など, 工学の領域でも取り入れられている ${ }^{14), 15 \% 。 ~}$

進化戦略は, 進化的計算法に分類される最適化のアルゴリズムで, 実数を直接扱える，適用に制限が少ないなどの特色を持つ ${ }^{13)}$ 。モデル を定式化してアルゴリズムに取り込む必要はなく，探索したパラメ 
一タの適合度の優少を判断できればいいことから，ここで扱うよう なシミュレーションに基づくパラメー夕探索に威力を発揮すると期 待される。本論文では，加速度計が高密度に配置された中層SRC建 物の強震記録を用い, 進化戦略によって地盤と建物の相互作用を考 慮した建物の振動特性を推定し，その特徴を考察する。

\section{2. 解析対象建物と観測記録}

独立行政法人建築研究所(以下建築研究所)は, 1957年以来建物を主 な対象とした強震観測を全国規模で行っている ${ }^{16)}$ 。1998年には建築研 究所の都市防災研究センター棟(以下新館と称する)の建設を機に, 新 館と研究本館, 及び周辺地盤を対象とした非常に密度の高い観測を 開始した ${ }^{17)}$ 。以下に新館建物及び観測システムの概要と, 本論文で使 用した観測記録について述べる。

\section{1 地盤条件}

建築研究所は, 茨城県つくば市の北部, 霞ヶ浦へ流れ込む桜川と 利根川支流の小貝川に挟まれた標高約 $30 \mathrm{~m}$ の洪積台地上に位置する。 観測施設の設置時に実施された地盤調查結果を表1に示す。地中 $88 \mathrm{~m}$ までは時折砂碟層を挟む粘土層と細砂層が主体となっている。深さ $88 \mathrm{~m}$ 及び深さ $42 \mathrm{~m}$ の砂磁層を入力としたときのSH波の伝達関数を図 1 に示す。図の(a)が $88 \mathrm{~m},(\mathrm{~b}) か ゙ 42 \mathrm{~m}$ ，図中には2004年10月6日の茨城 県南部の地震で観測された加速度記録のフーリエスペクトル比(地表 /GL-89m及びGL/GL-43m) も併せて示す。図からわかるように, $88 \mathrm{~m}$ の深さの地盤を考えると $0.8 \mathrm{~Hz}, 2 \mathrm{~Hz}$ 及び $4 \mathrm{~Hz}$ 付近に, 深さ $42 \mathrm{~m}$ の層を 考えると $1.5 \mathrm{~Hz}$ 及び $4 \mathrm{~Hz}$ 弱に卓越が見られ，伝達関数と観測記録のフ ーリエスペクトル比は良い対応を示している。

\section{2 建物の概要}

1998年3月に竣工した新館建物は地下 1 階, 地上8階建ての鉄骨鉄筋 コンクリート(SRC)造で, 地下部分はコンクリート(RC)造, 上部架棈

表1 建築研究所の敷地地盤構造

\begin{tabular}{|c|c|c|c|c|c|}
\hline No. & $\begin{array}{l}\text { 層厚 } \\
(\mathrm{m})\end{array}$ & $\begin{array}{c}V_{\mathrm{P}} \\
(\mathrm{m} / \mathrm{s})\end{array}$ & $\begin{array}{c}V_{\mathrm{S}} \\
(\mathrm{m} / \mathrm{s})\end{array}$ & $\begin{array}{c}\rho \\
\left(\mathrm{t} / \mathrm{m}^{3}\right)\end{array}$ & 土質 \\
\hline 1 & 2.0 & 170 & 110 & 1.30 & ローム \\
\hline 2 & 6.0 & \multirow{2}{*}{1430} & 200 & 1.30 & 砂質粘土/粘土質砂 \\
\hline 3 & 6.0 & & 160 & 1.50 & 砂質粘土/粘土 \\
\hline 4 & 8.0 & 1630 & 260 & 1.80 & 細砂/砂質細砂 \\
\hline 5 & 6.0 & 1500 & 200 & \multirow{2}{*}{1.75} & \multirow{2}{*}{ 砂質粘土/粘土 } \\
\hline 6 & 14.0 & 1570 & 270 & & \\
\hline 7 & 6.0 & 1880 & 460 & 1.90 & 砂硉 \\
\hline 8 & 8.0 & 1780 & 340 & \multirow{2}{*}{1.75} & \multirow{2}{*}{ 砂質粘土/粘土 } \\
\hline 9 & 12.0 & 1690 & 290 & & \\
\hline 10 & 12.0 & 1790 & 380 & 1.95 & 砂磷/細砂 \\
\hline 11 & 8.0 & 1600 & 280 & 1.75 & 砂質粘土/粘土 \\
\hline 12 & & & 500 & 2.00 & 砂䂺 \\
\hline
\end{tabular}

$V_{\mathrm{P}}: \mathrm{P}$ 波速度 $(\mathrm{m} / \mathrm{s}), V_{\mathrm{S}}: \mathrm{S}$ 波速度 $(\mathrm{m} / \mathrm{s}), \rho$ : 単位体積重量 $\left(\mathrm{t} / \mathrm{m}^{3}\right)$
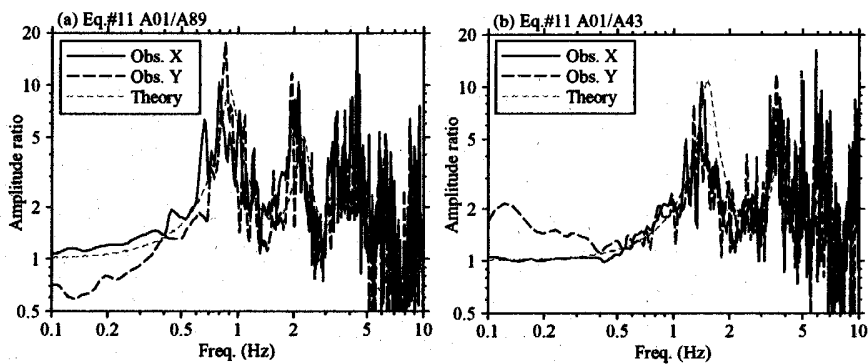

図1 表層地盤の増幅特性(左:深さ $88 \mathrm{~m}$, 右:深さ $42 \mathrm{~m}$
の一部が鉄骨(S)造となっている。構造的には，一部RC壁を有する骨

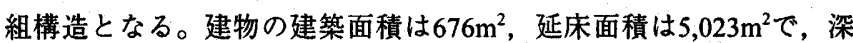
さ $8.2 \mathrm{~m}$ の粘土層に直接基礎によって支持されている。東に隣接する 本館建物との位置関係を図 2 に示す。新館と本館は構造的には互いに 独立しおり，エキスパンションジョイント(図中の破線部分)を介して， 渡り廊下によって結ばれている。

2.3 観測システム

竣工と同時に稼動した観測システムは，新館建物内11台，地盤内7
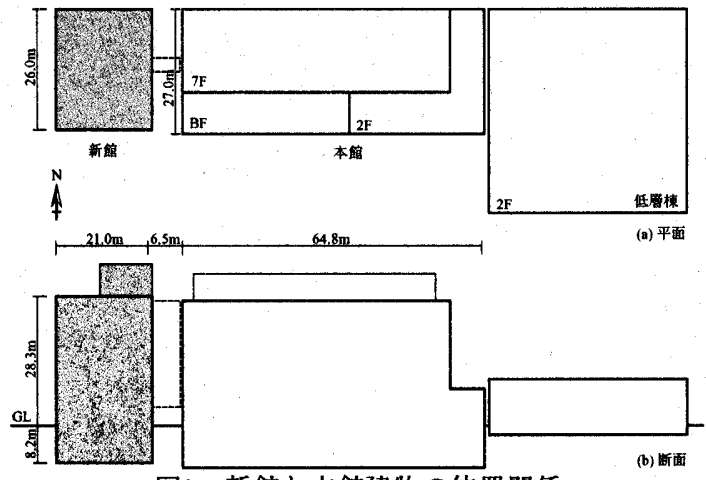

図2 新館と本館建物の位置関係

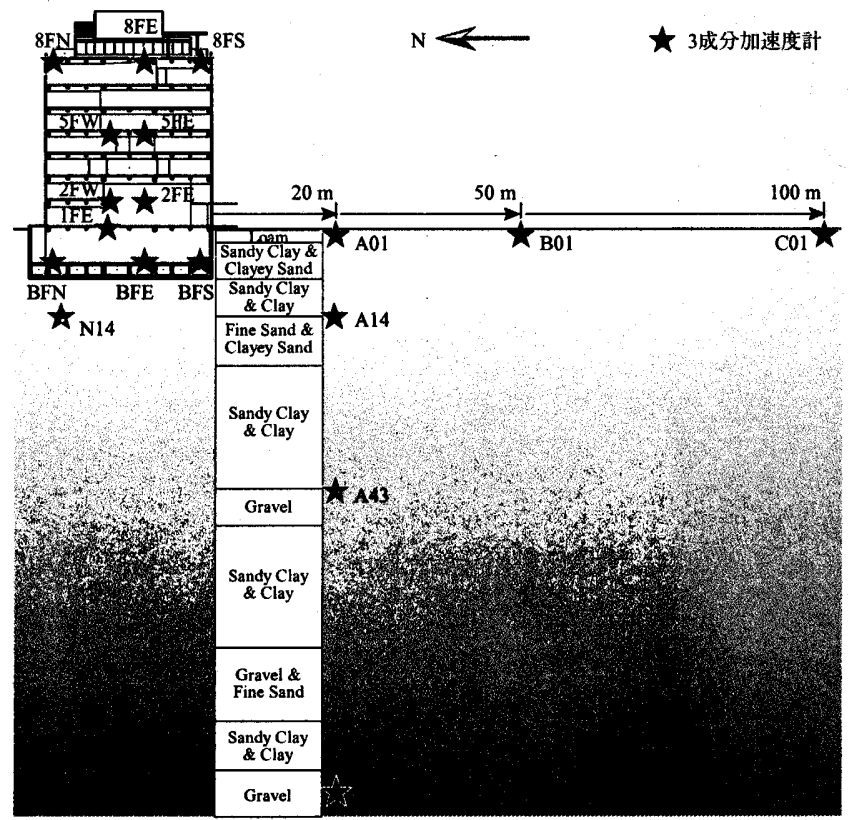

図3 新館建物内及び地盤内の加速度計の配置

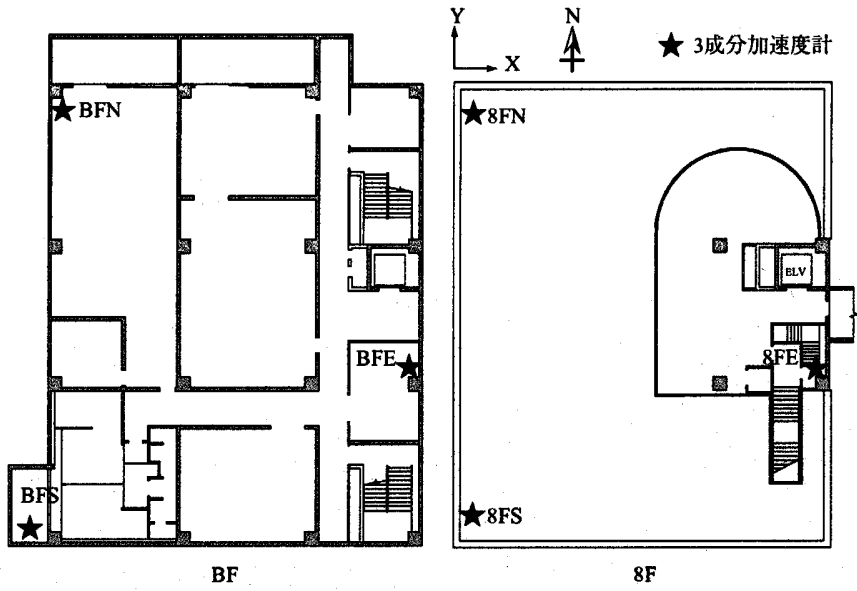

図4地下1階(BF)及び8階(8F)床レベルの加速度計の配置 
台，隣接する本館建物内4台の計22台の加速度計を有する。図3及び 図4に新館及び地盤内の加速度計の配置を示す。建物より最も離れて いる地盤上の加速度計は南方向に約 $100 \mathrm{~m} の$ 距離にあり, 最も深い加 速度計は地中深さ $89 \mathrm{~m}$ の砂䂺層に埋設されている。また, 建物の立体 的な挙動の把握を目的として, 地下 1 階及び8階にはそれぞれ3台の加 速度計を設置している(図3)。

全ての加速度計の記録は新館4階の強震観測室で集中収録されて いる。加速度計は全て変位帰還型で, 直流成分から測定が可能であ る。24bitのAD変換器を有しており，実効分解能は18 bit，ダイナミッ クレンジに換算して114dB相当となる。地中 $89 \mathrm{~m} に$ 埋設されている加 速度計(図3中A89)の3成分のうち，いずれかがトリガレベル $\left(1 \mathrm{~cm} / \mathrm{s}^{2}\right)$ を超えると収録を開始し，同じトリガレベルを60秒間連続で下回っ た時に収録を停止する。

建物の軸が東西-南北に一致しているため，建物の軸に合わせて設 置されている加速度計の方位も東西-南北に一致している。図4に示す ように, 以下の解析では東西方向(建物短辺方向)をX, 北南方向(建物 長辺方向)をYとして扱う。

\section{3 解析対象記録}

解析の対象とした記録は，1998年の観測開始から2005年8月までの 間に得られた 362 記録のうち，地表(図3のA01)の記録の計測震度換算 值で1.0以上の158記録である。これらの記録のうち建物の応答振幅が 比較的大きな16地震を選定し，5.2節以降の詳細解析に用いた。16記 録の地震諸元と地表(A01)の記録の計測震度及び最大加速度を表 $2 に$ 示す。最も大きな地表最大加速度は2002年6月14日茨城県南部の地震 (表2のNo.6)で記録した $74 \mathrm{~cm} / \mathrm{s}^{2}$ ，最も大きな計測震度は 2004 年 10 月 6 日茨城県南部の地震(No.11)で記録した3.8であり，現在までに建物の 主体構造に被害が生ずるような大きな地震動は経験していない。

なお，これらの観測記録のうち，新館建物8階の地下 1 階に対する 相対変位の最大值 $\left(d_{\max }\right)$ がX方向で $1 \mathrm{~cm}$ 超えた地震のNo.は斜体で, Y方向で $1 \mathrm{~cm}$ を超えた地震のNo.は太字で記している。 $d_{\max }$ の算出方法 については後述する。

表2 詳細解析の対象地震記録

\begin{tabular}{|r|c|l|r|r|r|r|r|}
\hline No. & 日時 & 震央地名 & $\begin{array}{c}h \\
(\mathrm{~km})\end{array}$ & $M$ & $\begin{array}{c}\Delta \\
(\mathrm{km})\end{array}$ & $I \mathrm{~s}$ & $\begin{array}{c}P G A \\
\left(\mathrm{~cm} / \mathrm{s}^{2}\right)\end{array}$ \\
\hline 1 & $1998 / 06 / 2423: 52$ & 茨城県南部 & 68 & 4.7 & 3 & 2.6 & 19.3 \\
\hline 2 & $1999 / 03 / 2608: 31$ & 茨城県北部 & 59 & 5.0 & 60 & 3.3 & 46.3 \\
\hline 3 & $1999 / 04 / 2521: 27$ & 茨城県北部 & 59 & 5.2 & 61 & 3.1 & 36.9 \\
\hline 4 & $2000 / 04 / 1006: 30$ & 茨城県南部 & 55 & 4.7 & 7 & 3.3 & 49.4 \\
\hline 5 & $2000 / 07 / 2103: 39$ & 茨城県沖 & 49 & 6.4 & 104 & 3.6 & 37.9 \\
\hline 6 & $2002 / 06 / 1411: 42$ & 茨城県南部. & 57 & 5.1 & 13 & 3.4 & 74.3 \\
\hline 7 & $2003 / 05 / 2618: 24$ & 宮城県沖 & 72 & 7.1 & 330 & 3.3 & 29.2 \\
\hline 8 & $2003 / 09 / 2012: 54$ & 千葉県南部 & 70 & 5.8 & 104 & 2.8 & 13.7 \\
\hline 9 & $2003 / 11 / 1503: 43$ & 茨城県沖 & 48 & 5.8 & 103 & 3.0 & 21.4 \\
\hline 10 & $2004 / 04 / 0408: 02$ & 荻城県沖 & 49 & 5.8 & 101 & 2.9 & 21.2 \\
\hline 11 & $2004 / 10 / 0623: 40$ & 茨城県南部 & 66 & 5.7 & 16 & 3.8 & 54.5 \\
\hline 12 & $2004 / 10 / 2317: 56$ & 新溜県中越地方 & 13 & 6.8 & 168 & 3.5 & 30.9 \\
\hline 13 & $2004 / 10 / 2318: 34$ & 新渴県中越地方 & 14 & 6.5 & 166 & 3.2 & 18.1 \\
\hline 14 & $2005 / 04 / 1107: 22$ & 千葉県北東部 & 52 & 6.1 & 66 & 3.4 & 25.9 \\
\hline 15 & $2005 / 07 / 2316: 34$ & 千葉県北東部 & 73 & 6.0 & 61 & 3.1 & 25.8 \\
\hline 16 & $2005 / 08 / 1611: 46$ & 宮城県沖 & 42 & 7.2 & 301 & 3.5 & 29.8 \\
\hline
\end{tabular}

$h:$ 震源深さ $(\mathrm{km}), M:$ 気象庁マグニチュード, $\Delta$ : 震央距離 $(\mathrm{km}), I \mathrm{~s}:$ 計 測震度相当值, $P G A$ : 地表最大加速度 $\left(\mathrm{cm} / \mathrm{s}^{2}\right)$

\section{3. 解析モデル}

\section{1 せん断型1質点系モデル}

建物の基本的な振動特性を検討する場合は，図5に示すようなせん 断型1質点系モデルを想定する。このモデルは質点の質量 $m$, 剛性 $k$, 減衰係数cの3つのパラメータを有し, 系の振動特性は固有振動数 $f_{0}$ と減衰定数 $h_{0}$ で表される。

3.2 せん断型多質点系モデル

建物の水平方向の振動特性の変動を詳細に検討する場合は，図6に 示すようなせん断型多質点系モデルを想定する。新館建物は8階建て であるが，8階より上の部分は他の階に比べて面積的，質量的に小さ いので8階床レベルに集約し，また地下1階は壁が多く変形は微小と 考えられるため一体の基礎と見做し，上部構造を7質点の等価せん断 型モデルに置換する。地盤と建物の相互作用を考慮する場合はこれ にロッキングとスウェイの自由度を加え，図6の左に示すようなスウ エイーロッキング(SR)モデルを想定した。ここで $m_{i}, I_{i}$ 及び $k_{\mathrm{i}}$ は各層 の質量, 回転慣性及び凮性 $(i=0, \cdots, 7), k_{\mathrm{R}}$ と $c_{\mathrm{R}}$ はロッキングの剛 性と減衰係数， $k_{\mathrm{S}}$ と $c_{\mathrm{S}}$ はスウェイの剛性と隇哀係数， $W$ とHは建物 の幅と高さである。ロッキングばねの取り付け位置は地下階の中心 (基礎底面から 1 階床までの高さの $1 / 2$ の高さ)とし，Hはロッキングば ねの取り付け位置からの高さである。

このモデルの場合, 建物頂部の変位に占めるスウェイの変位 $d_{\mathrm{S}}$, ロッキングの変位 $d_{\mathrm{R}}$, 建物のせん断変形による変位 $d_{\mathrm{B}}$ は, 図6の右 側に示した各測定点の絶対変位から以下のように算出される。

$$
\begin{aligned}
& d_{\mathrm{S}}=d_{\mathrm{BF}}-d_{\mathrm{GL}} \\
& d_{\mathrm{R}}=\left(d_{\mathrm{BL}}-d_{\mathrm{BR}}\right) H / W
\end{aligned}
$$$$
d_{\mathrm{B}}=d_{\mathrm{RF}}-d_{\mathrm{GL}}-d_{\mathrm{S}}-d_{\mathrm{R}}
$$

ここで $d_{\mathrm{GL}}, d_{\mathrm{BF}}, d_{\mathrm{RF}}$ はそれぞれ地表, 建物基礎, 建物頂部の 水平絶対変位, $d_{\mathrm{BL}}$ と $d_{\mathrm{BR}}$ は建物基礎の左右の鉛直絶対変位であり, 添え字は図6右の測定点に対応している。なお，8階より上の階の質 量は8階床レベルに集約しているため, 建物頂部は図3及び図4中の8F

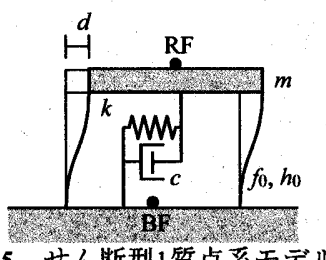

図5 せん断型1質点系モデル

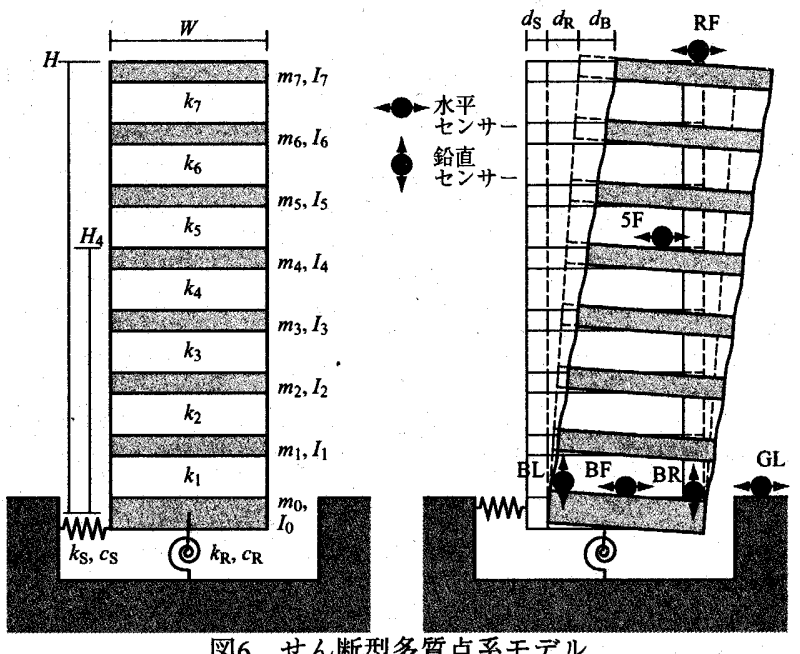

図6 せん断型多質点系モデル 
に相当する。 $d_{\mathrm{BF}}$ と $d_{\mathrm{RF}}$ は床平面中央の值を採るものとし, 図4の各 測定点の変位から算定する。また $d_{\mathrm{BL}}$ と $d_{\mathrm{BR}}$ は地下 1 階の 3 点の上下 動から算出する。X方向では, 下式のようになる。

$$
\begin{aligned}
& d_{\mathrm{BF}}=\left({ }_{\mathrm{X}} \delta_{\mathrm{BFN}}+{ }_{\mathrm{X}} \delta_{\mathrm{BFS}}\right) / 2 \\
& d_{\mathrm{RF}}=\left({ }_{\mathrm{X}} \delta_{8 \mathrm{FN}}+{ }_{\mathrm{X}} \delta_{8 \mathrm{8FS}}\right) / 2 \\
& d_{\mathrm{BL}}=\left({ }_{\mathrm{z}} \delta_{\mathrm{BFN}}+{ }_{\mathrm{z}} \delta_{\mathrm{BFS}}\right) / 2 \\
& d_{\mathrm{BR}}={ }_{\mathrm{Z}} \delta_{\mathrm{BFE}}
\end{aligned}
$$

ここで， $\delta$ は図4に示した加速度計から算出した絶対変位で, 左添 え字X，Y及びZは方向成分，右添え字は測定点を示す(図4参照)。一 方, Y方向では $d_{\mathrm{BL}}$ と $d_{\mathrm{BR}}$ は建物の中心軸での值が算出できないので 西端の上下動で代用し, 下式で算出している。

$$
\begin{aligned}
& d_{\mathrm{BF}}=\left({ }_{\mathrm{Y}} \delta_{\mathrm{BFN}}+{ }_{\mathrm{Y}} \delta_{\mathrm{BFE}}\right) / 2 \\
& d_{\mathrm{RF}}=\left({ }_{\mathrm{Y}} \delta_{8 \mathrm{FN}}+{ }_{\mathrm{Y}} \delta_{8 \mathrm{FE}}\right) / 2 \\
& d_{\mathrm{BL}}={ }_{\mathrm{Z}} \delta_{\mathrm{BFS}} \\
& d_{\mathrm{BR}}={ }_{\mathrm{Z}} \delta_{\mathrm{BFN}}
\end{aligned}
$$

なお, BF/GLのフーリエスペクトル比をとると, 連成系の1次固有 振動数ではBF/GLの振幅比は殆ど低下しないため, 入力損失の影響は 小さいと判断し，SRモデルの入力(GL)は地表の記録(図3のA01)をそ のまま用いている。入力は水平動のみとし, 回転入力は考慮しない。

5.2節の検討で初期値として使用する建物の質量は, 設計時の地震 荷重設定用に算定された值を用いた。また建物の剛性も設計時に実 施された骨組解析から得られた弾性時の層せん断力と層間変位の值 から算出した。ロッキングとスウェイの剛性は表1の地盤構造を用い て，一様地盤の弾性理論解にコーンモデルを用いた成層地盤の補正 を施す簡便法 ${ }^{18.19)}$ で算定する。このとき埋め込みの影響は側面土圧と

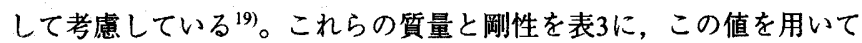

表3建物の振動パラメータ

\begin{tabular}{|c|r|r|r|}
\hline \multirow{2}{*}{ 層 } & \multirow{2}{*}{$\begin{array}{c}\text { 質量 } \\
\mathrm{t} /\left(\mathrm{m} / \mathrm{s}^{2}\right)\end{array}$} & \multicolumn{2}{|c|}{ 剛性 $\left(\times 10^{3} \mathrm{t} / \mathrm{m}\right)$} \\
\hline 7 & 114.1 & 79.9 & \multicolumn{1}{c|}{$\mathrm{Y}$} \\
\hline 6 & 75.9 & 130.2 & 117.3 \\
\hline 5 & 78.3 & 145.7 & 129.9 \\
\hline 4 & 95.0 & 153.7 & 135.8 \\
\hline 3 & 79.8 & 168.5 & 150.3 \\
\hline 2 & 80.1 & 186.4 & 214.2 \\
\hline 1 & 85.3 & 295.6 & 1058.3 \\
\hline $0 / \mathrm{S}$ & 128.8 & 554.5 & 554.5 \\
\hline & \multicolumn{2}{|c|}{$\begin{array}{l}\mathrm{x} I=2.710 \times 10^{4} \mathrm{t} \cdot \mathrm{m}^{2} /\left(\mathrm{m} / \mathrm{s}^{2}\right) \\
\mathrm{x} k_{\mathrm{R}}=8.932 \times 10^{7} \mathrm{t} \cdot \mathrm{m} \\
\mathrm{y} I=4.154 \times 10^{4} \mathrm{t} \cdot \mathrm{m}^{2} /\left(\mathrm{m} / \mathrm{s}^{2}\right) \\
\mathrm{y} k_{\mathrm{R}}=1.257 \times 10^{8} \mathrm{t} \cdot \mathrm{m}\end{array}$} \\
\hline
\end{tabular}

注) $I=\sum I_{i}$, 左添え字は方向

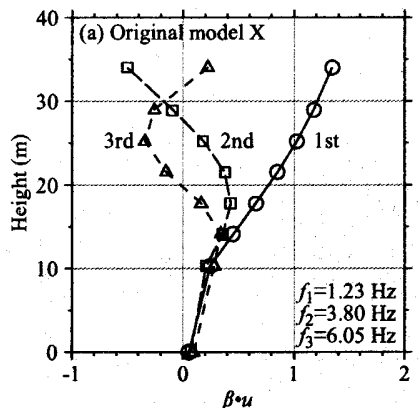

図7初期の剛性を用いたSRモデルの振動モード
算出した3次までの固有振動モー ドを図7に示す。

\section{4. 解析手法}

地震時の建物の固有振動数や 剛性, 減衰定数などの振動パラメ 一夕を観測記録から推定するこ とは，観測記録を最も精度よく説 明し得るパラメータを探索する， 非線形最適化の問題と捉えるこ とができる。本論文では最適化の 対象に応じて2つの方法を用いる。

\section{1 最急降下法}

$n$ 個の成分を持つ実数べクトル

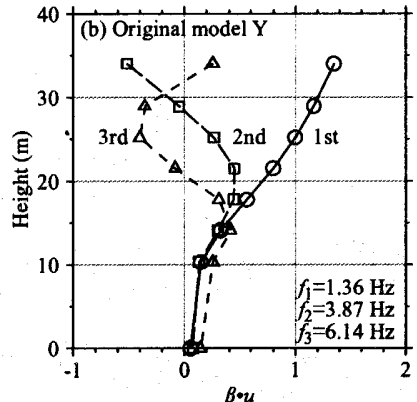

$\mathrm{x}=\left(x_{1}, \cdots, x_{n}\right)$ を変数として取る関数 $f(\mathbf{x})$ の最小化問題を考える時, 目的関数が単純な場合, 単一の探索点を順次改良して行き, 最適な 変数を探索する方法が有効である。ここではその中でも簡明な最急 降下法 ${ }^{10), 13)}$ を採用する。

最急降下法では, $j$ 番目の探索点 $\mathbf{x}^{(j)}=\left(x_{1}^{(j)}, \cdots, x_{n}^{(j)}\right)$ から次の探索点 の成分を以下の式で与える。

$$
x_{i}^{(j+1)}=x_{i}^{(j)}-a\left(\frac{\partial f}{\partial x_{i}}\right), \quad(i=1, \cdots, n)
$$

ここで，aは降下の速度を規定する係数である。この方法は，い くつかの振動パラメータを変数とし, 観測値とシミェレーションが 最も適合する振動パラメータを探索するアルゴリズムとして利用で きる。この場合，関数 $f(\mathbf{x})$ はパラメー夕の適合度を示す值を返す。 本論文で扱う事例では適合度を表す関数 $f(\mathbf{x})$ の値はシミュレーショ ンから評価し, 微係数を直接求められないので, $\partial f / \partial x_{i}$ は下式の差 分で近似する。

$$
\frac{\partial f}{\partial x_{i}} \approx \frac{f\left(x_{1}, \cdots, x_{i}+\Delta x_{i}, \cdots, x_{n}\right)-f\left(x_{1}, \cdots, x_{i}, \cdots, x_{n}\right)}{\Delta x_{i}}
$$

ここで， $\Delta x_{i}$ は $x_{i}$ の微小な移動量である。この方法は目的関数の 值が小さくなる方向に順次探索点を移動してゅく基本的な降下法で あり，正しい解を得るには探索範囲内で $f(\mathbf{x})$ の極小值が単一である 必要がある。ただし，下り勾配を辿って最小值が探索できるように 探索の開始点を設定できれば，複数の極小値を持つ関数にも適用可 能となる。

\section{2 進化戦略(ES)}

進化戦略(Evolution Strategy: ES)は遺伝的アルゴリズム等と同様に, 生物の進化から着想された多点探索のアルゴリズムである。1960年 代にRechenberg とSchwefelによって基礎的なアルゴリズムが確立さ れ，以降改良が進められてきた201,21)。遺伝的アルゴリズムに比べ，(i) 実数を直接探索する, (ii)突然変異を主要な探索点生成の手段として いる，(iii)変数間の相関を考虑できるなどの特色がある。また，適合 度の評価関数を定式化する必要がなく，その優劣を判断できればい いことからここで扱うシミュレーションなどその適用範囲は広い。 本論文では, 以上のような特徵から, 振動モデルの各部の剛性や減 衰定数を直接かつ効率良く最適化するために進化戦略を採用する。

進化戦略には, 親個体の個数と子個体の個数の採り方からいくつ かのバリエーションが存在する。ここでは，個の親個体から $\lambda$ 個の 子個体を生成し, 適合度の高いものから順に $\mu$ 個を次世代の親個体と して残す進化戦略手法 $((\mu, \lambda)$-ES と表記される)を採用し， $\mu=30$, $\lambda=200$ とした。 $n$ 個の成分を持つべクトル $\mathrm{x}=\left(x_{1}, \cdots, x_{n}\right)$ を変数とする 関数 $f(\mathbf{x})$ の最小化問題を考えるとき，ひとつの個体は変数 $\mathbf{x}$, 正規 分布の標準偏差 $\sigma=\left(\sigma_{1}, \cdots, \sigma_{n}\right)$ 及び成分間の相関を考慮するパラメ 一夕 $\boldsymbol{\alpha}=\left(\alpha_{1,2}, \cdots, \alpha_{(n-1), n}\right)$ から構成される。今個体を $\mathbf{a}=(\mathbf{x}, \boldsymbol{\sigma}, \boldsymbol{\alpha})$ とし, 個体の集合を $\mathbf{P}=\left(\mathbf{a}_{1}, \cdots, \mathbf{a}_{m}\right)$ とする。この時 $\mathbf{P}$ に含まれる個体の数 $m$

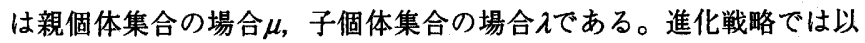
下の手順で個体の進化を模擬し，優れた個体の探索を行う。

$0)$ 世代 $t(t=0)$ の親個体の集合 $\mathbf{P}_{t}$ を生成する。

1) $\mathbf{P}_{t}$ より組み換えにより子個体の集合 $\mathbf{P}_{t}^{\prime}$ を生成する。

2） $\mathbf{P}_{t}^{\prime}$ より突然変異により子個体の集合 $\mathbf{P}_{t}^{\prime \prime}$ を生成する。

3) $\mathrm{P}_{t}^{\prime \prime}$ 評価し, 適合度の高いものから $\mu$ 個の個体を選択し, 次世 代の親個体集合 $\mathbf{P}_{t+1}$ とする。 
4) 終了判定を行い，条件を満たさなければ1)へ戻る。

組み換えと突然変異による個体の生成, 次世代の個体の選択, 終 了判定は以下の方法で行う。

1) 組み換え

$(\mu, \lambda)$-ESでは複数の親個体を有するため, 親個体の組み換えによっ

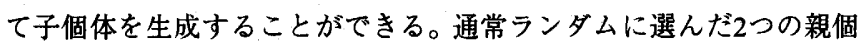
体に操作を加え, 子個体を生成する。この操作にはいくつかの方法 が存在するが, 本論文では変数 $x_{i}$ については成分毎にいずれかの親 の值を継承することとし，付随するパラメータ $\sigma_{i}$ や $\alpha_{i, j}$ については2 つの親の成分の值の中点を子の成分の值とする。

2) 突然変異

進化戦略の主要な操作である突然変異は, 個々の成分に随伴する 標準偏差 $\sigma$ と成分間の相関を考慮するためのパラメー夕 $\boldsymbol{a}$ から与え られる摂動を加えて行う。次の世代の $\boldsymbol{\sigma}^{\prime}$ と $\boldsymbol{\alpha}^{\prime}$ の成分は， $\boldsymbol{\sigma}$ と $\boldsymbol{\alpha}$ から 下式によって算出される。

$$
\begin{aligned}
& \sigma_{i}^{\prime}=\sigma_{i}+\exp \left(\tau_{0} N(0,1)+\tau N_{i}(0,1)\right), \quad(i=1, \cdots, n) \\
& \alpha_{i, j}^{\prime}=\alpha_{i, j}+\beta N_{i, j}(0, N), \quad(i=1, \cdots, n-1 ; j=i+1, \cdots, n)
\end{aligned}
$$

ここで $N(0,1), \quad N_{i}(0,1), \quad N_{i, j}(0,1)$ は各々独立した標準正規乱数を 表す。 $\tau_{0}, \tau$ 及び $\beta$ は定数であり，推奖されている值 ${ }^{20), 21)}$ を採用し， $\tau_{0}=1 / \sqrt{2 n}, \tau=1 / \sqrt{2 \sqrt{n}}, \beta=0.0873$ とする。この結果から次の世 代の変数 $\mathbf{x}^{\prime}$ は下式で与えられる。

$$
\mathbf{x}^{\prime}=\mathbf{x}+\zeta
$$

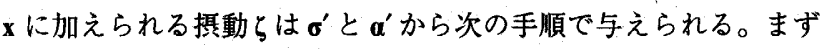
各成分独立に平均 0 , 標準偏差 $\sigma_{i}^{\prime}$ の正規乱数を発生しべクトル る。

$$
\eta_{i}=\sigma_{i} N_{i}(0,1)
$$

また, 回転変換を行う行列 $\mathbf{R}_{i, j}=\left\{r_{i, j}\right\}$ を考え, その要素を下式で 与える。ただし他の要素は, 対角要素が1, 非対角要素が0となる。

$$
\begin{aligned}
& r_{i, i}=r_{j, j}=\cos \alpha_{i, j}^{\prime} \\
& r_{i, j}=-r_{j, i}=\sin \alpha_{i, j}^{\prime}
\end{aligned}
$$

全ての $\mathbf{R}_{i, j}$ をに作用させ，下式よりちを作る。

$$
\zeta=\prod_{i=1}^{n-1} \prod_{j=i+1}^{n} \mathbf{R}_{i, j} \boldsymbol{\eta}
$$

\section{3) 選択(淘汰)}

生成された $\lambda$ 個の子個体の適合度を評価し, 適合度の高いものから 順に $\mu$ 個を次世代の親個体として残す。

4) 終了判定

最適解の適合度が判っていれば, 探索点の適合度が十分に最適解 の適合度に近づいた時に探索を終了する。最適解の適合度が不明な 場合は，探索に十分な世代数を与えるか，世代を重ねてもそれ以上 の解の改善が見込めない場合に打ち切るような工夫が必要となる。 5.2節以降の解析では, 最適解の適合度を見積もることが困難なため, 十分な世代数を与えることとし，200世代の進化演算を行い，最も優 れた個体を解として採用する。

\section{5. 建物の振動特性の経年変動}

\section{1 振動特性の基本的性啠}

対象建物の振動特性の基本的な性質を把握するため, X方向及びY 方向の 1 次の固有振動数と減衰定数の経年変動を検討する。このため 図5の1質点系モデルを想定し，基礎位置の記録を入力として建物頂
部の相対变位応答(図 5 の)が最も適合する固有振動数 $f_{0}$ と隇衰定数 $h_{0}$ を以下の手順で探索する。

1) $0.4 \mathrm{~Hz}$ から $4 \mathrm{~Hz}$ の振動数区間を $0.1 \mathrm{~Hz}$ 刻みで予備探索し，最も適 合度の高い振動数を見つける。予備探索では減衰定数は $5 \%$ に固 定した。

2) 前項で求めた振動数と隇衰定数 $5 \%$ 開始点として, 最急降下法 によって最も適合する固有振動数と減衰定数を探索する。

適合度は観測とシミュレーションの相対变位の差の二乗の総和で 評価し，下式で算出する。

$$
F\left(f_{0}, h_{0}\right)=\int_{T_{f}}\left(d^{s}-d^{o}\right)^{2} d t
$$

$f_{0}$ と $h_{0}$ は振動系の固有振動数と減衰定数, $d^{o}$ と $d^{s}$ はそれぞれ観 測とシミュレーションから得られた頂部の基礎に対する相対変位で ある。観測の相対変位は, 8階と地下階の中央部の水平加速度を高速 フーリエ変換(FFT)によって積分し，その差をとる。積分の時，遮断 振動数 $0.3 \mathrm{~Hz}$ のローカットフィルターを用いている。 $T_{\mathrm{f}}$ は適合度を判 定する時間区間で，相対変位が最大值となる時間を中心に前後各 10 秒間の計 20 秒間を採っている。なお, 入力を建物基礎の, 出力を建 物頂部の水平動としているため, ここで求めた振動特性には地盤と 建物の相互作用効果のうち, ロッキングの影響が含まれている $\left(d^{o}\right.$ 及 び $d^{s}$ は図6の $\left(d_{\mathrm{B}}+d_{\mathrm{R}}\right)$ に相当する)。

全記録について上記方法で求めたX方向と $\mathrm{Y}$ 方向の固有振動数 $f_{0}$ と減衰定数 $h_{0}$ を図8に示す。上段(a)が固有振動数, 中段(b)が滅衰定 数を表す。また下段(c)は固有振動数のうち, (a)図のAの部分の拡大 図(Y方向のみ)である。図中横軸には期日(年)を採っている。菱形(〉) がX方向に, 四角( $\square$ )がY方向に対応し, 記号の大きさ(及び色の濃さ) は頂部の相対変位の最大值 $d_{\text {max }}$ に対応している。 $d_{\text {max }}$ が $1 \mathrm{~cm}$ を超え る比較的大きな応答を示した地震は, 表2の地震番号が斜体(X方向) または太字(Y方向)で示されたものである。
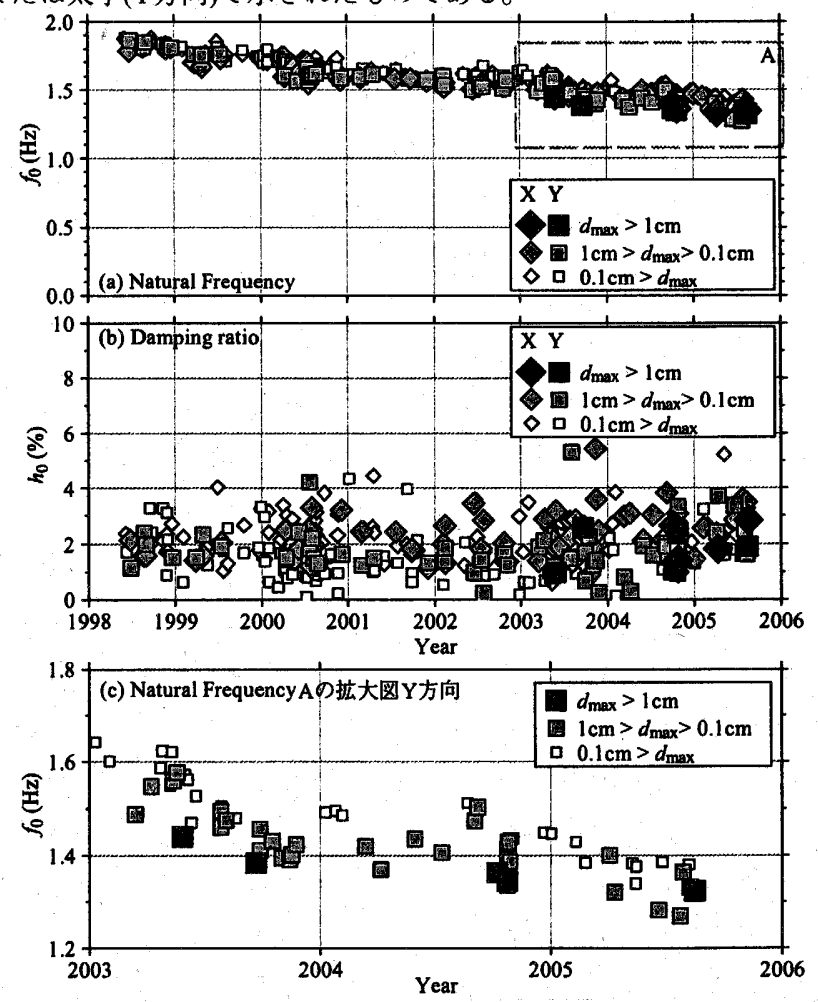

図8 1次固有振動数と減衰定数の経年変動 
図8の(a)に着目し, 全体的な変動を見ると, 経年に伴う固有振動数 の低下が激しく, 1998年の竣工当時 $1.8 \mathrm{~Hz}$ から $1.9 \mathrm{~Hz}$ であった固有振動 数が，7年後の 2005 年には $1.3 \mathrm{~Hz}$ から $1.4 \mathrm{~Hz}$ に低下している。図8の(c) に着目し，詳細に観察すると，大きな振幅の地震(句を経験すると， 以降の中小地震(曰や口)の固有振動数もそれ以前に比べて低くなって いる。つまり大きな振幅の地震が固有振動数の低下の原因になって いる可能性が高い。また，同じ時期でも最大変位振幅が大きな記録 では固有振動数が低くなる傾向が認められ，振幅に依存した変動も 観察できる。なお図8(b)の減衰定数については，変動の幅が大きいも のの，経年や振幅の大きさとの明暸な相関は認められない。

\section{2 地盤と建物の相互作用を考虑した振動特性の経年変動}

上述した固有振動数の低下の原因を検討するため, 図6に示したSR モデルを用いて，各パラメータの最適化を行う。最適化の対象は建 物，ロッキングとスウェイの剛性 $\left(k_{i}, k_{\mathrm{R}}\right.$ と $\left.k_{\mathrm{S}}\right)$, 及び建物の1次モ 一ド隇衰定数 $\left(h_{1}\right)$ とし, 高次のモード隇衰定数は剛性比例型とする。 建物の剛性についてはその分布形状は変わらないものとし, 初期剛 性に対する比率を最適化する。またロッキング及びスウェイの判性 についても初期値を与え, 初期値に対する比率を最適化の対象とす る。

$$
\begin{array}{ll}
r_{\mathrm{B}} & =k_{i} / k_{i}^{0}, \quad(i=1, \cdots 7) \\
r_{\mathrm{R}} & =k_{\mathrm{R}} / k_{\mathrm{R}}^{0} \\
r_{\mathrm{S}} & =k_{\mathrm{S}} / k_{\mathrm{S}}^{0}
\end{array}
$$

ここで， $k_{i}^{0}$ は層の剛性の初期值， $k_{\mathrm{R}}^{0}$ と $k_{\mathrm{S}}^{0}$ はロッキングとスウエ イの剛性の初期值で，3.2節で述べた值を用いている。

なお，ロッキング及びスウェイの減衰定数については，振幅レベ ルが小さいこと, 深さ $42 \mathrm{~m}$ の砂喽層を支持層と考えれば連成系の固有 振動数が地盤の卓越振動数より小さくなることから材料隇衰のみ考 慮して $5 \%$ に固定し ${ }^{22)}$, 隇衰俰数を $c_{\mathrm{R}}=2 h_{\mathrm{R}} k_{\mathrm{R}} / \omega_{1}, c_{\mathrm{S}}=2 h_{\mathrm{S}} k_{\mathrm{S}} / \omega$ の形 で与えている。ここで, $h_{\mathrm{R}}$ 及び $h_{\mathrm{S}}$ はロッキング及びスウェイの減衰 定数 $(5 \%), \omega$ は振動系の1次固有円振動数である。

各剛性の比や滅衰定数の最適化には進化戦略を用いる。結局, 最 適化の対象のパラメータは $r_{\mathrm{B}}, r_{\mathrm{R}}, r_{\mathrm{S}}$ 及び $h_{1}$ のつで, 計算過程で は各值の常用対数を採っている。適合度の判定は, 頂部における建 物のみの相対変位(図6右の $d_{\mathrm{B}}$ ), 頂部におけるロッキングの変位 $\left(d_{\mathrm{R}}\right)$, スウェイの変位 $\left(d_{\mathrm{S}}\right)$ のつについて, 次式に示す観測値と解析 值の差の二乗和で行う。

$$
\begin{aligned}
& F\left(r_{\mathrm{B}}, r_{\mathrm{R}}, r_{\mathrm{S}}, h_{1}\right)= \\
& w_{\mathrm{B}} \int_{T_{\mathrm{f}}}\left(d_{\mathrm{B}}^{s}-d_{\mathrm{B}}^{o}\right)^{2} d t+w_{\mathrm{R}} \int_{T_{\mathrm{f}}}\left(d_{\mathrm{R}}^{s}-d_{\mathrm{R}}^{o}\right)^{2} d t+w_{\mathrm{S}} \int_{T_{\mathrm{f}}}\left(d_{\mathrm{S}}^{s}-d_{\mathrm{S}}^{o}\right)^{2} d t
\end{aligned}
$$

ここで, 上付きのo及びsは観測及びシミュレーションによる変位 であることを示す。観測記録の変位は, 各測定点の絶対加速度をFFT によって積分し，式(1)から式(3)に従い算出する。このとき，建物の1 次モードに着目するため, 建物の 1 次固有振動数を中心に $0.5 \mathrm{~Hz}$ の幅 のバンドパスフィルター処理を行う。シミュレーションの変位は図6 のモデルを用い, 線形地震応答をモーダルアナリシスによって求め る。 $w_{\mathrm{B}}, w_{\mathrm{R}}, w_{\mathrm{S}}$ は建物, ロッキング, スウェイの変位振幅の差 を補正する重み係数で，各変位成分の最大振幅の二乗が同一となる ように設定する。 $T_{\mathrm{f}}$ は適合度を判定する時間区間で，頂部の基碟に 対する相対変位が最大となる時刻の前5秒，後 15 秒の 20 秒間を探る。 進化戦略をこの事例に適用する場合, 地震動の特性によって最適解
の適合度が変動し，探索の終了のための目標適合度を設定するのが 困難であるため, 常に200世代計算し, 最も適合度の高い個体を最適 解として採用する。

地震番号11のY方向について, 最適化されたパラメータを使ったシ ミュレーション結果の例を，観測記録と比較して図9に示す。上の4 波が絶対加速度で, 上から(a)建物頂部(RF), (b)ロッキング, (c)建物 基礎( $\mathrm{BF})$, 及び(d)地表(GL)の加速度である。ロッキングの加速度は, 基礎の回転の加速度に建物高さ $H$ を乗して頂部の水平方向の加速度 に換算した。また，下の3波が変位の時刻歴波形で，上から(e)頂部に おける建物変位 $d_{\mathrm{B}},(\mathrm{f})$ ロッキング変位 $d_{\mathrm{R}},(\mathrm{g})$ スウェイ変位 $d_{\mathrm{S}}$ であ
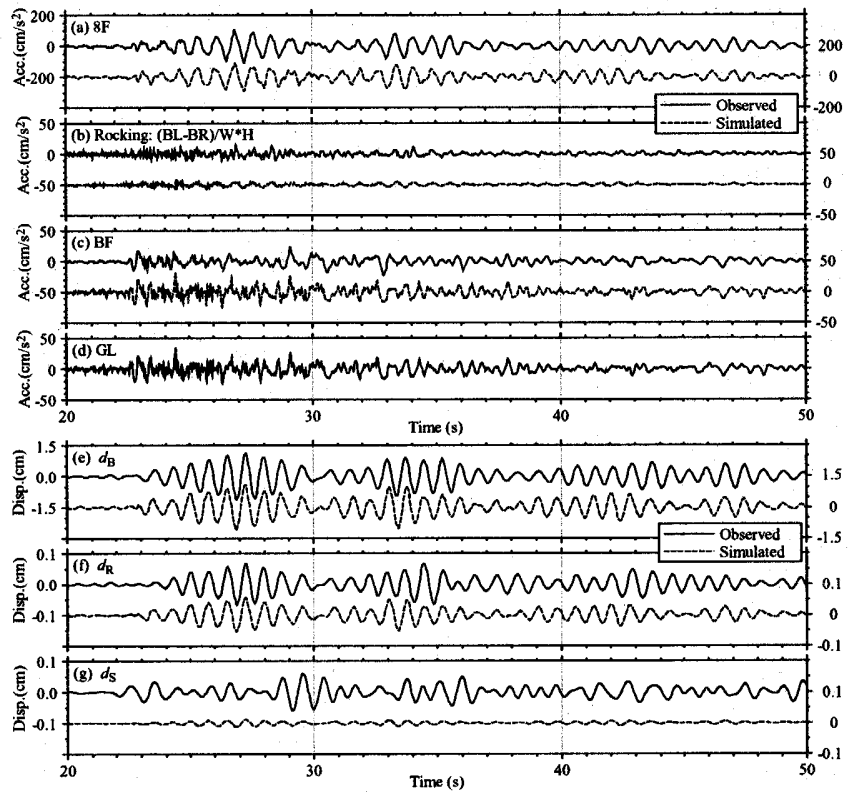

図9 観測記録とシミュレーションの比較
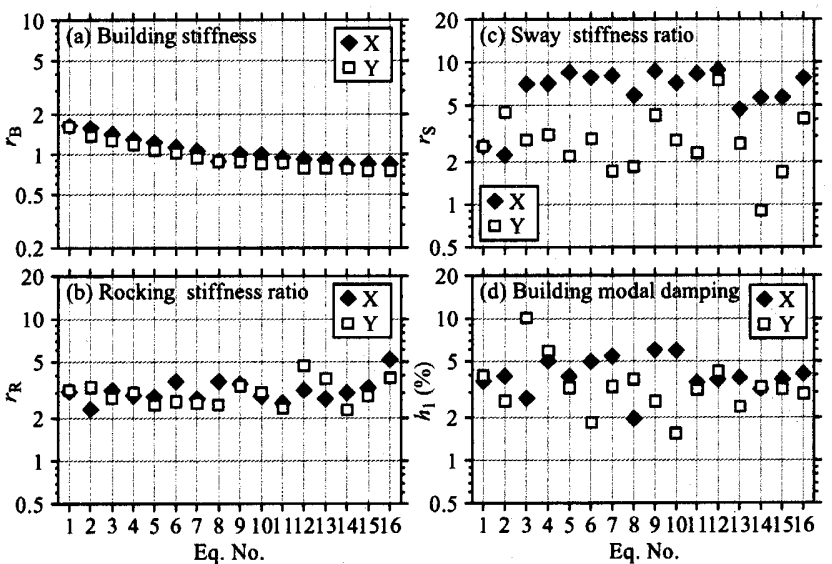

図10 $r_{\mathrm{B}}, r_{\mathrm{R}}, r_{\mathrm{S}}$ 及び $h_{1}$ の最適化結果
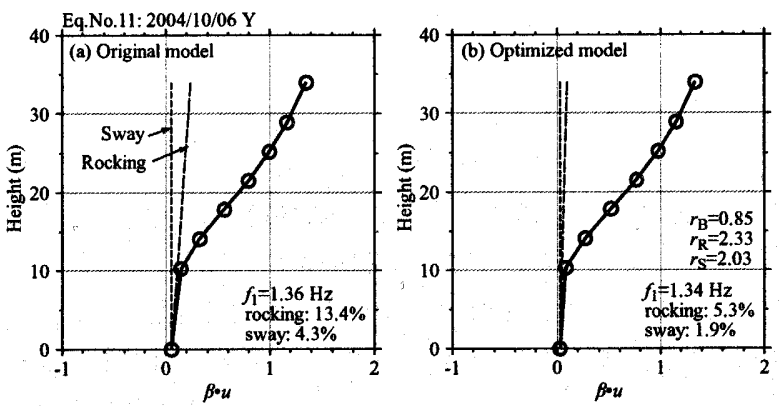

図11 初期剛性(左)と最適化剛性(右)による1次モードの比較 
る。各波形の実線が観測結果, 破線がシミュレーションの結果で, (d) 以外は比較のために観測波形とシミュレーション波形の基線をずら してある。スウェイの変位に違いが認められるが, 詳細に見ると大 きな波の位相や包絡形に相違があり，ここで採用したSRモデルでは 説明できない振動成分が載っている影響と思われる。それを考慮す ればいずれの波形もシミュレーションは良く観測結果を説明してお り，各パラメータが適切に評価できていることが判る。

表2の16地震の記録に対して求めた $r_{\mathrm{B}}, r_{\mathrm{R}}, r_{\mathrm{S}}$ 及び $h_{1}$ を図10に示 す。図中, 左上(a)が建物剛性の比 $r_{\mathrm{B}}$, 左下(b)がロッキング剛性の比 $r_{\mathrm{R}}$, 右上(c)がスウェイ剛性の比 $r_{\mathrm{S}}$, 右下(d)が建物の1次モード減衰 $h_{1}$ で, 各図中の記号は, 菱形 $(\diamond)$ は建物X方向の結果を, 四角 $(\square)$ は 建物Y方向の結果を表す。図中の横軸には地震番号(表2参照)を採っ ている。建物剛性の設計で想定した剛性に対する比 $r_{\mathrm{B}}$ は, 竣工直後 は1.7程度であったが, 現在では1を割り，0.8程度となっている。口 ッキング剛性の比 $r_{\mathrm{R}}$ は安定した值を示し， 3 前後の值となっている。 一方スウェイの剛性比 $r_{\mathrm{S}}$ は, $r_{\mathrm{R}}$ に比べてばらつき, 2 から10程度の 值をとる。ロッキングの剛性比やスウェイの剛性比に経年に伴う変 動の明瞭な傾向は認められない。建物の1次モード減衰定数 $h_{1}$ は, 若 干のばらつきはあるものの, 概ね3\%から $5 \%$ の値となっており, 平均 値を取るとX方向で4.1\%, Y方向で3.6\%となっている。また地震番号 3，6，9，10ではX方向とY方向の隇衰定数に大きな差が表れている。 この原因については別途検討する必要があるが，片方が大きくなる と他方が小さく推定されておう，据れなどの建物の立体的な挙動が 影響している可能性も考えられる。

以上見てきたように，ロッキング剛性，スウェイ剛性及び建物の 減衰定数に期間変動は認められず, 建物の剛性に明らかな減少が見 られることから，前節で述べた全体系の固有振動数の経年変動は主 に建物の特性の変化に起因すると結論付けられる。観測期間中の建 物の質量が大幅に変動したことはなく, 建物の特性の変化は結局剛 性低下ということになる。

図11は最適化前後の1次固有モードの比較である。左(a)が初期值と して採用した剛性によるY方向の1次モード, 右(b)が地震番号11につ いて最適化した後の剛性によるY方向の1次モードである。この場合, 建物の剛性は初期值の0.85倍, ロッキング剛性は2.33倍, スウエイ剛 性は2.03倍の值が最適解として得られている。建物の各層の剛性分布 は一定としているので全体的な形状は大きくは変わらないが, 頂部 変位に占めるロッキングの変位の割合(ロッキング率)は, 初期モデル で13.4\%であったものが最適化モデルでは5.4\%になっている。また, スウェイ変位の割合(スウェイ率)は初期モデルが $4.3 \%$, 最適化モデル が1.9\%と，やはり最適化結果のほうが小さくなる。なお，地震番号5 について，波形処理から算出したロッキング率は8\%から $11 \%$ ，スウ エイ率は $2 \%$ から $3 \%$ であり 5.3 上部構造の振動特性の経年変動

前節の解析で, 観測期間中の新館建物の固有振動数の低下は, 建 物の剛性の低下に起因することが確認できた。本節では建物の剛性 を1階から4階までの下層と, 5階から7階までの上層に分けてどの部 分の㴊性が低下しているのかを検討する。また, 着目点は建物の応 答の変動であるので, 図6の解析モデルのBFを入力位置として探り, ロッキングのみを考慮したモデルを想定する。この場合, 前節と同 様進化戦略を最適化手法として採用し, 建物の剛性は $r_{\mathrm{B} 1}$ と $r_{\mathrm{Bu}}$ の2
つのパラメータで表す。 $r_{\mathrm{B1}}$ は建物の下層(1階から4階)の剛性の初期 值に対する比率, $r_{\mathrm{Bu}}$ は建物の上層(5階から7階)の剛性の初期値に対 する比率で，下式で表される。

$$
\begin{aligned}
& k_{i}=r_{\mathrm{Bl}} k_{i}^{0},(i=1, \cdots 4) \\
& k_{i}=r_{\mathrm{Bu}} k_{i}^{0},(i=5, \cdots 7)
\end{aligned}
$$

ここで, 各階の剛性の初期值 $k_{i}^{0}$ は前節と同様設計時の值を用いる。 ただし, ロッキング剛性の初期値 $k_{\mathrm{R}}^{0}$ は, 前節で得られた結果 $r_{\mathrm{R}}$ の16 地震の平均值で補正し, 前節の初期值に対しX方向は3.1倍, Y方向は 3.0倍して用いる。結局, 最適化の対象は $r_{\mathrm{Bl}}, r_{\mathrm{Bu}}, r_{\mathrm{R}}$ 及び $h_{1}$ のつ のパラメータとなる。また，適合度は下式で評価する。

$$
\begin{aligned}
& F\left(r_{\mathrm{Bu}}, r_{\mathrm{Bl}}, r_{\mathrm{R}}, h_{1}\right)= \\
& w_{\mathrm{Bu}} \int_{T_{\mathrm{f}}}\left(d_{\mathrm{Bu}}^{s}-d_{\mathrm{Bu}}^{o}\right)^{2} d t+w_{\mathrm{Bl}} \int_{T_{\mathrm{f}}}\left(d_{\mathrm{Bl}}^{s}-d_{\mathrm{Bl}}^{o}\right)^{2} d t+w_{\mathrm{R}} \int_{T_{\mathrm{f}}}\left(d_{\mathrm{R}}^{s}-d_{\mathrm{R}}^{o}\right)^{2} d t
\end{aligned}
$$

ここで， $d_{\mathrm{Bu}}$ と $d_{\mathrm{Bl}}$ はそれぞれ建物頂部の5階床に対する相対変位 と5階床の基礎に対する相対変位, $w_{\mathrm{Bu}}, w_{\mathrm{Bl}}$ は前節と同様, 各変位 の振幅レベルの差を調整するための重みである。 $d_{\mathrm{Bu}}, d_{\mathrm{B} 1}$ は図6に 示した測定点の記録を使って次式で算出する。

$$
\begin{aligned}
& d_{\mathrm{Bu}}=d_{\mathrm{RF}}-d_{5 \mathrm{~F}}-d_{\mathrm{R}} \\
& d_{\mathrm{Bl}}=d_{5 \mathrm{~F}}-d_{\mathrm{BF}}-d_{\mathrm{R}} H_{4} / H
\end{aligned}
$$
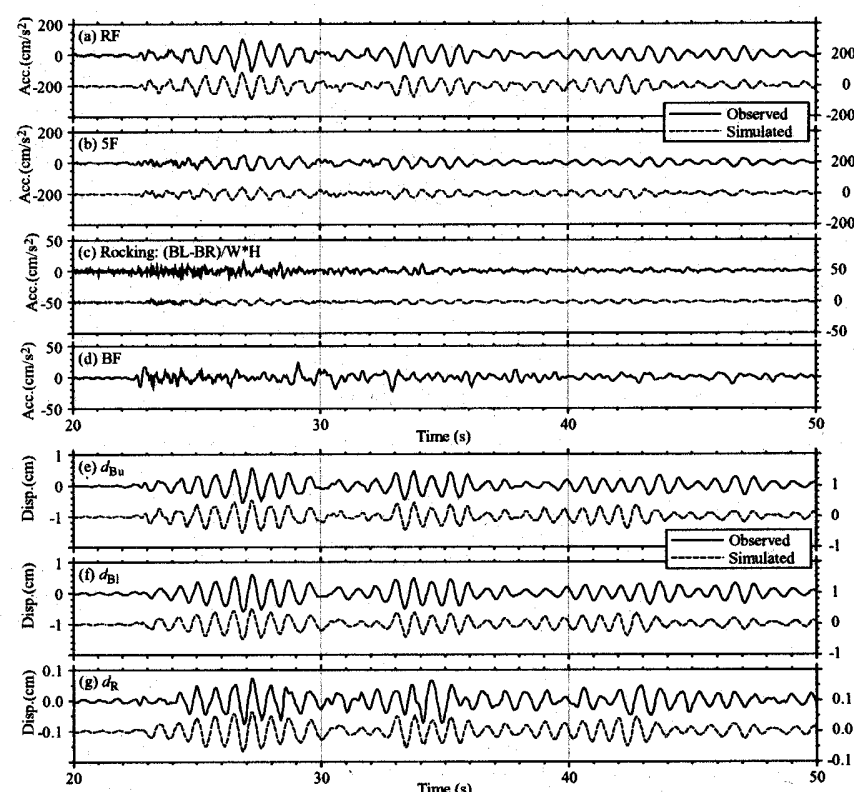

図12 観測記録とシミュレーションの比較

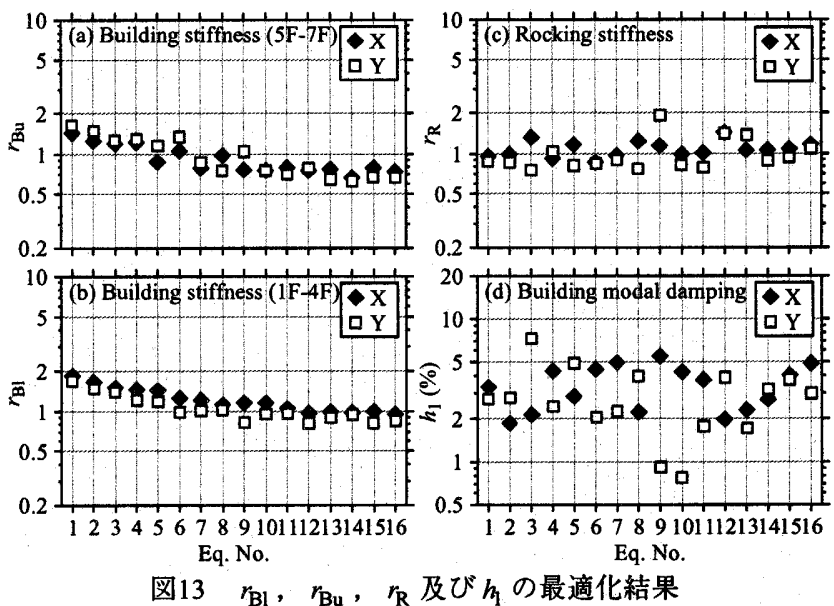

図13 $r_{\mathrm{Bl}}, r_{\mathrm{Bu}}, r_{\mathrm{R}}$ 及び $h_{1}$ の最適化結果 
ここで， $d_{5 \mathrm{~F}}$ は5 階床(質点4)の絶対変位で， $H_{4}$ はその測定点まて の高さである。変位は前節と同様に加速度記録からFFTによって求め るが，この時用いたバンドパスフィルターは，高次の振動成分まで 考慮するため, $1.0 \mathrm{~Hz}$ から $5.0 \mathrm{~Hz}$ までの成分が通過する特性とする。

地震番号11のY方向について，最適化の結果を用いてシミュレーシ ヨンを行った波形を，観測記録と比較して図12に示す。上の4波が絶 対加速度で, 上から (a)建物頂部(RF), (b)建物5階(5F), (c)ロッキング, 及び(d)入力である地下階(BF)の波形である。下の3波が変位の時刻歴 で, 上から(e)建物頂部の5階床に対する建物の相対変位 $d_{\mathrm{Bu}}$, (f)建物 5 階床の基礎に対する建物の相対変位 $d_{\mathrm{Bl}},(\mathrm{g})$ 口ッキング変位 $d_{\mathrm{R}}$ の 波形である。加速度も変位も実線の波形が観測結果，破線の波形が シミュレーション結果を表す。いずれの時刻歴波形も極めてよく近 似できており，最適化された各パラメータの妥当性が確認できる。

表2の16地震の記録について得られた $r_{\mathrm{Bl}}, r_{\mathrm{Bu}}, r_{\mathrm{R}}$ 及び $h_{1}$ の最適 値を図13に示す。図中菱形 $(\diamond)$ は建物X方向, 四角 $(\square)$ は建物Y方向に 対応する。左上(a)が建物上層の剛性の比 $r_{\mathrm{Bu}}$, 左下(b)が建物下層の 剛性の比 $r_{\mathrm{B} 1}$, 右上(c)がロッキングの剛性比 $r_{\mathrm{R}}$, 右下 $(\mathrm{d})$ が建物の1次 のモード減衰定数 $h_{1}$ で，横軸には地震番号を採る。

建物の上層の剛性の比 $r_{\mathrm{Bu}}$ と下層の剛性の比 $r_{\mathrm{Bl}}$ を比較すると, 值 は上層のほうが若干小さいが, 全体的な低下の様相はよく似ている。 建物の全体的な剛性が, 地震番号16の時点では地震番号 1 に比べて半 分程度に低下したと考えられる。

一方ロッキングの剛性は, あらかじめ初期值を前節の結果で補正 しているため，1前後に分布している。また建物の1次モード減衰定 数も図10の結果とほほ同様の傾向を示す。

\section{6. 結論}

建築研究所新館建物について, 高密度に設置された加速度計の記 録を用い,その振動特性の変動の分析を行った。せん断型1質点系モ デルを用いた基本的な振動特性の検討では，経年による明暸な1次固 有振動数の低下が認められた。新館建物の1次固有振動数は竣工後の 7年間で約 0.7 倍に低下している。

変動の要因を詳細に分析するため，ロッキングとスウェイを有す るせん断型多貿点系モデルを想定し, 各部の剛性と建物の隇衰定数 の最適化を行った。最適化にあたっては，生物の進化の過程から着 想された進化的計算法のうち，実数を直接扱え，適用に制約が少な い進化戦略を用いた。本論文の事例では振動パラメータを適切に最 適化することができた。

得られた結果から，ロッキング，スウェイ及び建物のモード隇衰 定数に増加や減少の傾向は見られず, 固有振動数の低下は主に建物 の特性変化に起因すると確認された。対象建物は研究室や会議室と して使われており，観測期間中に大きな積載荷重の変動はなかった ことを考えると，建物の水平剛性が低下したものと考えられる。建 物の上層と下層に分けて剛性を最適化した結果では，何れも剛性が 1/2程度に低下しており，建物全体の等価なせん断剛性が低下したと 判断できる。

建物の剛性低下の原因は詳細な調査を行わなければ特定できない が，2次部材のなじみ，構造体の微細なひび割れなどが想定される。 現時点の剛性は設計時に想定された值の0.8倍程度であり，また剛性 の低下が落ち着きつつある様子も窥える。今後とも振動特性の変化
を注意深く見守る必要がある。

本論文の解析では, 建物の振動特性は中小の地震動を経験するこ とによっても少なからず変動することが確認された。現状ではこの 事例が特異な例であるかを判断するための観測事例が十分に蓄積さ れているとは言い難い。今後観測事例を増やして，様々な現象に対 する知見を蓄積し，振動特性の変動の解釈と，その幅の評価方法を 確立することが重要である。

\section{謝辞}

本稿をまとめるにあたり、国土技術政策総合研究所飯場正紀博士 に貴重な助言を頂いた。ここに記して謝意を表す。

\section{参考文献}

1）田中貞二: 日本における強震計の開発と初期の強震観测，ORI研究報告 94-02, 大崎総合研究所, 1994.10

2) 小山信，飯場正紀，鹿嶋俊英：建物の強震観測現状調查，日本建築学会大 会学術講演梗概集, B-2, p.877, 2004.8

3) Okawa, I., T. Kashima, K. Yamagishi, and M. Watakabe: Strong motion recording for buildings in Japan, Third UJNR Workshop on Soil-Structure Interaction, Building Research Institute, 2004.3

4) 日本建築学会: 建築構造物の振動実験, 1978.12

5）日本建築学会：建築物の滅衰，日本建築学会, 2000.10

6) 斎藤知生, 横田治彦: 1995 年兵庫県南部地震の記録を用いた建物振動特 性の同定, 日本建築学会大会学術講演梗概集, B-2, p.509, 1996.9

7) 斎藤知生: モード解析型多入力多出力 ARXモデルを用いた高層建物のシ ステム同定，日本建築学会構造系論文集, No.508,pp.47-54, 1998.6

8) 星谷勝, 斉藤悦郎: 格拥カルマンフィルターを用いた同定問題の各種振動 系への応用，土木学会論文報告集, No.338,pp.59-67, 1983.11

9) 古川忠稳，伊藤雅史，小野聡子，槅英三郎: 実地震観測記録を用いた2棟の 免震建物動特性の同定, 日本建築学会構造系論文集, No.558, pp.117-124, 2002.8

10) 片山徹: システム同定入門, 朝倉書店, 1994.5

11) 中村充, 竹脇出, 安井譲, 上谷宏二：限定された地震観測記録を用いた建 築物の剛性と減衰の同時同定, 日本建築学会構造系論文集, No.528, pp.75-82, 2000.2

12）吉元怜毅, 三田彰: 部分空間法及び部分構造アプローチを用いた免震構造 物の層㴊性及び減衰の同時同定, 日本建築学会構造系論文集, No.569, pp.31-36, 2003.7

13) 長尾智晴: 最適化アルコリススム, 昭晃堂, 2000.5

14）山中浩明, 石田寛: 遗伝的アルゴリズムによる位相速度の逆解析, 日本建 筑学会構造系論文集, No.468, pp.9-17, 1995.2

15) 田守伸一郎, 松谷有袏, 林善太郎: 多質点系構造物モデルにおける遺伝的 アルコリズムによる免震装置の最適選択計画, 日本建築学会構造系論文 集, No. 588 , pp.63-70, 2005.2

16) 鹿嶋俊英: 建築研究所の強震観測, 防災科学技術研究所研究資料, No.264, pp.33-39, 防災科学技術研究所, 2005.3

17）鹿嶋俊英，大川出，小山信: 8階建SRC造建物における地震観測と観測記録 から見た相互作用特性，第11回日本地震工学シンポジゥム論文集，地瞥工 学会, 2002.11

18）飯場正紀, 三浦賢治，古山田耕司: 地表面基礎の静的地篮ばねの簡便法, 日本建築学会大会学術講演梗概集, B-2, p.303, 2000.9

19) 国土交通省住宅局建築指導課他編集: 2001 年版限界耐力計算法の計算例と その解説, 工学図書, 2001.3

20) Bäck, T., D. B. Forgel and Michalewicz ed.: Evolutionary Computation 1 , Institute of Physics Publishing, 2000.5

21) 日本ファジィ学会編集: ファジィとソフトコンピューティングハンドブ ック，共立出版，2000.9

22）飯場正紀，三浦賢治，古山田耕司：地表面基碟の等価粘性減衰定数の簡便 評価法，日本建築学会大会学術講演梗概集, B-2, p.873, 2001.9

(2005年10月 8 日原稿受理，2006年 1 月 10 日採用決定） 